TAPROBANICA, ISSN 1800-427X. October, 2011. Vol. 03, No. 02: pp. 50-51.

(C) Taprobanica Private Limited, Jl. Kuricang 18 Gd.9 No.47, Ciputat 15412, Tangerang, Indonesia.

\title{
EDITORIAL
}

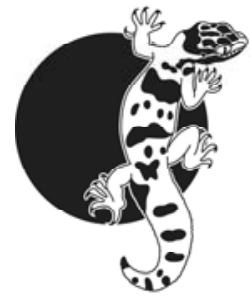

\section{Natural History Today and Tomorrow}

Although it is often said that the 19th Century was the epoch Natural History, the most substantial efforts in the study of nature and natural history will almost certainly be recorded during the 21st Century, which Alain Dubois (2010) has dubbed "the century of extinctions". We will thus be learning more about nature at the same time that we may be witnessing its wholesale demise. Still, today it is not too late to change course, through a greater appreciation of Natural History. In most societies science and technology are today predominant. This editorial argues that natural history is an equally important field of knowledge - one that knits together the work of biogeography, taxonomy, ecology, ethology, and evolution. Knowledge and appreciation of natural history underpins all actions that sustain the wealth of nature, which, in turn, underpins the future of our every-day existence (Alonzo et al., 2011).

My plea is thus for naturalists and natural history - the very foundation of humankind's study of life on earth (Beehler, 2010). The practice of natural history, in the face of global change and the threat of a looming extinction crisis, is needed now more than ever (Greene, 2005 \& references therein). Dubois (2010) and Cotterill \& Foissner (2010) highlighted the shortage of taxonomic expertise that hinders the comprehensive enumeration of this planet's species. Other types of expertise are needed as well, and well as other tools and interventions, as we aspire to a more fruitful and biodiverse $22^{\text {nd }}$ Century.

I list these below:

Step 1: Children growing up in nature. Many of the very best professional naturalists began as children whose sense of curiosity about the outdoors was fostered by supportive parents. Much has been written in the West about this current century's nature-free childhood in which most entertainment comes from electronic devices (Louv, 2008). Parents who care about their children ensure that they often get out-ofdoors, in nature. Today, many parents are too busy to encourage childhood leisure in nature. And yet child naturalists mature to become the best natural historians and field scientists.

Step 2: Schools teaching natural history. Politicians and pundits around the world decry the poor state of public schooling. One big step towards better schools and improved education is for educators to embrace nature as a critical central theme for an enriching curriculum. For a twelve-year-old, it is more important to learn the names of backyard species, cloud types, and the cycle of the seasons than to memorize the chemical structure of DNA.

Step 3: Nature clubs forming. Every community should sponsor a nature club that gets young people out into nature on weekends and during the school holidays. Mountain-climbing, bird-watching, snakecollecting, and other natural pursuits are critical to build the minds and bodies of our youth. All need to be instilled with the understanding of humankind's close bond to nature.

Step 4: Universities creating departments of natural history. Programmers and modelers abound in universities, but what of naturalists - field experts who can identify species and who study the wealth of nature? Modeling is for naught without the strong field data to power the model. Conservation biology is all the rage with students today, but how can conservation be successful without the natural history data informing intelligent planning and reserve design? Universities should be encouraging the study of nature and species. Departments of Natural History can bring together those who are seeking to enumerate the species on earth and their place in the many ecosystems that make up the biosphere.

Step 5: Governments investing in natural history. What happened to the world's natural history surveys? They closed down before their mandate was achieved. Who is going to collect, curate, and name the millions of undescribed species on earth? Every forward-thinking country should resurrect a strong natural history survey whose objective is to discover, map, and name its species. 
Step 6: Treaties supporting nature and traditional knowledge. The many multilateral treaties purporting to support the earth's natural resources need to re-boot and to refocus on nature, natural places, and wild species, and also to support traditional cultures as stewards of nature and traditional knowledge about nature.

Step 7: Multilaterals recognizing nature. The World Bank and the regional development banks need to bring nature back into their investment planning. Institutions that are interested in investing in carbon should also be willing to invest in forests for their biodiversity values. These are critical to a more livable biosphere.

Step 8: Economists valuing nature. Economic analyses must include nature's services in their reckoning. Only then can we begin to find a pathway to an environmentally sustainable global economy.

Step 9: Institutes pursuing unknown nature. Museums and research institutes need to reach back to their roots, and to attempt to capture that inspiration that comes from the study of wild nature. Research scientists need to take time from their molecular labs and get out into the field more often practicing the art of natural history.

Step 10: Laws supporting nature. We all know the term "natural law," but perhaps we have forgotten our links to nature when creating laws and regulations. Care for and better understanding of nature should be fundamental tenets that underpin each nation's network of laws and regulations.

Let's all remember-it's Nature first and foremost, not "biodiversity.” Biodiversity was just a way of making nature seem complex and "scientific," and more fundable by donor agencies. As scientists, naturalists, and citizens, we all must advocate for Nature. Each of us must proudly declare ourselves to be Naturalists. Recognition of Nature's primacy should inform everything we do. Only this way we can take back the future- a future that features the wealth of Nature.

\section{Literature Cited}

Alonso, L., J. L. Deichmann, S. A. McKenna, P. Naskrecki and S. J. Richards (Eds)., 2011. Still counting...: biodiversity exploration and conservation - the first 20 years of the Rapid Assessment Program. Conservation International, Arlington, Virginia: 316.

Beehler, B. M., 2009. The forgotten science: a role for natural history in the twenty-first century? Journal of Field Ornithology, 81(1): 1-4.

Cotterill, F. P. D. and W. Foissner, 2010. A pervasive denigration of natural history misconstrues how biodiversity inventories and taxonomy underpin scientific knowledge. Biodiversity Conservation, 19: 291-303.

Dubois, A., 2010. Taxonomy in the century of extinctions: taxonomic gap, taxonomic impediment, taxonomic urgency. Taprobanica, 2 (1): 1-5.

Greene, H. W., 2005. Organisms in nature as a central focus for biology. Trends in Ecology and Evolution, 20 (1): 24-26.

Louv, R., 2008. Last child in the woods: saving our children from nature-deficit disorder. Algonquin Books, New York: 214.

Bruce M Beehler

Sectional Editor: Taprobanica, the journal of Asian Biodiversity

March $3^{\text {rd }}, 2011$

Biodiversity Assessment

Division of Science and Knowledge

Conservation International

2011 Crystal Drive, Suite 500

Washington, DC 22202

USA 